\title{
Pigmented Spindle Cell Nevus
}

National Cancer Institute

\section{Source}

National Cancer Institute. Pigmented Spindle Cell Nevus. NCI Thesaurus. Code C4751.

A benign, small and slightly elevated brown or black skin lesion with usually welldemarcated borders. It is characterized by the presence of a melanocytic proliferation resulting in the formation of uniform cellular nests. Sometimes the clinical and morphologic features may be difficult to distinguish from melanoma. 